Снежана Поповић

Универзитет у Београду

Филолошки факултет

Катедра за славистику

s.popovic@fil.bg.ac.rs
УДК 81'27

https://doi.org/10.18485/slavistika.2021.25.2.5

Оригиналан научни рад примљено 15.7.2021.

прихваћено за штампу 6.10.2021.

\title{
ПОЈАМ МОНОКОЛОКАБИЛНОСТИ И ПЕРИФЕРИЈА ЈЕЗИКА
}

У раду представљамо устаљене спојеве у чешком језику у којима се као саставни елемент јавља лексема врло ограничене колокабилности тј. затворене колокативне парадигме. Дате спојеве смо потражили у Чешком националном корпусу који нам омогућава претраживање и у паралелном корпусу InterCorp, на основу кога сазнајемо који су њихови најчешћи еквиваленти у српском језику. Циљ рада је представљање моноколокабилности и указивање на начине на које се у лингвистичким истраживањима ових двају језика могу користити могућности електронских паралелних корпуса.

Кључне ријечи: колокабилност, чешки језик, српски језик, Чешки национални корпус, Корпус савременог српског језика.

The paper presents the conception of language periphery and discusses set phrases in the Czech language in which words of limited collocability occur. We looked for such phrases in the Czech National Corpus, which allows us to search in the InterCorp parallel corpus and look up the most common equivalents in the Serbian language. We looked for some of them in the Corpus of Contemporary Serbian. The aim of the research is the frequency of the mentioned phrases in these two modern languages and the variety of the translation equivalents.

Keywords: collocability, Serbian language, language periphery, Czech language, Serbian language, Czech National Corpus, Corpus of Contemporary Serbian.

1.

Истраживања способности лексема да се повезују и граде спојеве дала су многа занимљива сазнања о колокацијама. Њима се пажња у радовима и монографијима код нас посебно посвећује посљедњих двадесет година. ${ }^{1}$ Сви аутори указују на то колико можемо сазнати о лексемама на основу њиховог међусобног повезивања, премда њихова мишљења по питању дефиниције колокације нису јединствена. Према Липки, колокација представља синтагматску комбинацију лексичких јединица, независно од врсте ријечи и синтаксичке структуре (Драгићевић 2007: 218). Уводећи овај појам у лингвистику 30-их година XX вијека, Ферт је посматрао значење колокације одвојено од контекста, наглашавајући да та два значења нису иста (Firth 1957: 195). Стога када разматрамо овакав спој лексема ван контекста, односно колокацију као један минималан контекст, говоримо о колоцирању које у себе укључује појам колокабилности.

Колокабилност се дефинише као могућност уланчавања лексема (Prćić 2008: 150) тј. као способност њиховог удруживања (Дражић 2014: 37). Појам колокација у чешку лингвистику увео је Ф. Чермак (Čermák 1982). Сматрајући да су колокације кључ за упознавање начина и правила понашања лексема,

\footnotetext{
${ }^{1}$ B. (Riđanović 1988; Prćić 2008; Stojičić 2010, 2012; Дражић 2014; Стојичић 2011).
} 
као и њихових граница, Чермак их назива неопходним елементом у спознаји значења (Čermák 2006: 10). Запажа се, дакле, да је настанак колокација условљен колокабилношћу и компатибилношћу лексема. Колокабилност Чермак описује као комбинаторну способност лексема или њихов синтагматски потенцијал. Говори, такође, о комбинаторном принципу као о могућности језичких јединица да се у нове деноминације удружују у комбинацијама свих врста ријечи (С̌ermák 2007: 26).

Комбинаторика ${ }^{2}$ или комбинаторна способност лексема се у неким случајевима чини неограничена, но испитивања на обимним корпусима не говоре томе у прилог.

\section{2.}

Лексеме колоцирају са различитим бројем других лексема, а у језику постоје и оне чији се синтагматски потенцијал остварује са изузетно малим бројем других лексичких јединица. Палмер као примјер за то у енглеском језику наводи придјев rancid, који се јавља само уз butter или bacon (Palmer 1976: 97). Ако желимо било који сличан појам да означимо одликом „,it tastes or smells unpleasant because it is no longer fresh" (Oxford 2006), морамо употребити други придјев. Насупрот томе постоје лексеме које је фреквентна употреба довела до колокативне презасићености, као што је случај са придјевима леп и добар у српском језику (Драгићевић 2007: 87). У приручнику Periferie jazyka - Slovník monokolokabilnich slov Чермак посвећује посебну пажњу управо оним лексемама које показују ограниченост у свом удруживању. Он у уводу упозорава да је овај приручник по својој суштини један нов и необичан рјечник. Посвећен управо оним ријечима које Чермак назива моноколокабилним или моноспојивим у ширем смислу (monokolokabilni/jednospojitelná slova), ${ }^{3}$ он баца посебно свијетло на лексичке облике за које чак може бити тешко одредити којој врсти ријечи припадају. Разлог за то лежи у облику дате лексичке јединице у коме се она најчешће појављује, те остали не бивају у употреби (нпр. сви падежни облици неке именске ријечи) или говорницима нису ни познати. Само колоцирање са малим бројем лексема постаје узроком ограниченог броја облика. У првом дијелу приручника су моноколокабилне ријечи наведене као одреднице према фреквенцији појављивања у стомилионском репрезентативном корпусу SYN2010 Чешког националног корпуса (ЧНК), почев од оних најфреквентнијих према Херфиндал-Хиршмановом индексу, ${ }^{4}$ а у рјечничком одјељку сазнајемо о колокатима са којима се јављају и учесталости појављивања, док су у другом

2 У. Хајд користи термин комбинаторика као област у чијем је домену описивање селективних својстава лексичких јединица, колокација и идиома на основу електронских корпуса (Heid 1994: 226).

3 ,It is the collocability of a lexical form which is clearly defined by its being combinable with only a few (2-7), or a strictly speaking, only one another form in a language. This single form (or forms) prevents the given lexeme from its linguistic extinction, because without combining, in a state of isolation, nothing is possible in language" (Čermák 2007: 81).

${ }^{4}$ Најфреквентнији изрази су са бројем појављивања вишим од 500 и међу првих десет одредница су: najevo, vidění, líto, nahlas, známo, zapotřebi, třešničkou, divu, pěšky и zadarmo. 
дијелу рјечника одреднице распоређене абецедно. Ови подаци нас несумњиво наводе на закључак да ово јесте нов и необичан тип рјечника.

3.

У овом раду желимо првенствено да представимо изабране моноколокабилне ријечи у чешком језику које су у поменутом рјечнику Ф. Чермака наведене као фреквентне. Ограничили смо се на број јединица који одговара обиму овога рада. Поред описа у лексикографским приручницима, занимају нас и њихови еквиваленти у српском језику. Циљ нашег рада је, дакле, и да дођемо до сазнања да ли неки еквивалент анализираних моноколокабилних ријечи показује особине изразито ограничене спојивости документоване претрагом у Корпусу савременог сриског језика. Још важнији циљ јесте да укажемо на који се начин у лингвистичким истраживањима ових двају језика могу користити могућности електронских паралелних корпуса, ${ }^{5}$ стога ћемо у приказ уврстити примјере из књижевних дјела српских и чешких аутора којима ћемо допунити сазнања о еквиваленцији.

Како се, дакле, дефинише моноколокабилност? Моноколокабилност је својство појединих лексема да се јављају унутар врло затворених колокативних парадигми, тј. с ограниченошћу колокативних спрега. Примјери таквих спојева у чешком језику су: dát/vyjít najevo, skutková podstata, stát za vidění, udělat/být na úkor, otevř́t/nechat dokořán, ani nedutal, nechat/zůstat na holičkách, dát někomu něco na rozmyšlenou, v preveážné většině, nenínebylo divu (Čermák 2014). Неки од њих су из домена фразеологије (udělat/být na úkor, otevřit/nechat dokoř́n, ani nedutal, nechat/ zůstat na holičkách), односно стручне терминологије (skutková podstata).

Истакнуте лексеме се најчешће јављају у датим спојевима и премда се за неке може рећи да припадају промјенљивим врстама ријечи, било именицама (úkor, holičkách), придјевима (rozmyšlenou, převážné), док друге припадају непромјенљивим тј. прилозима (najevo, dokořán), најзаступљенији су облици у савременом чешком језику у којима се јављају у датим устаљеним спојевима. У наставку рада ћемо посебну пажњу посветити изразима: dát/vyjít najevo, udělat/ být na úkor, otevř́t/nechat dokořán, ani nedutal, nechat/zůstat na holičkách, dát někomu něco na rozmyšlenou и v prevážné většině.

Прилог najevo је у рјечнику књижевног чешког језика Slovník spisovného jazyka českého (SSJČ) објашњен на сљедећи начин:

- najevo př́sl. tak, že se stává zřejmým, jasným, patrným, са наведеним примјерима vyjit/dávat najevo. У Чешко-српском речнику (ЧСР) је такође, без посебне обраде значења, наведен само у датим спојевима са значењем: открити, отворено изнети, показати, давати до знања.

Именица мушког рода úkor представљена је у трима значењима:

- úkor †1. přikoří, křivda, bezpráví; 2. na úkor koho, čeho; †3. na úkor komu, с̌ети (SSJČ), односно 1. неправда, 2. срамота, брука 3. у вези: na úkor koho,

\footnotetext{
${ }^{5}$ Допринос овоме већ је дала К. Митрићевић-Штепанек у раду „Аугментативи у српском и чешком језику у Чешком националном корпусу” обављеном у Славистици XXIV/2 прошле године.
} 
čeho; на штету кога, чега (ЧСР), од којих су два застарјела. ${ }^{6}$ Управо у овом значењу на штету кога, чега заступљено је у савременом језику и на то указује претраживање у електронском корпусу чешког језика. У првом дијелу Periferie jazyka - Slovník monokolokabilních slov úkor се налази на седамнаестом мјесту са 1346 појављивања у спојевима na úkor, jiných; ostatních; kvality; bylo; druhých; lidi; jde (Čermák 2014). У свим спојевима је именица úkor окамењена и не јавља се ни у једном другом падежу. Притом ЧНК показује да се израз најмање користи у реченицама у којима је субјекат исказан у првом лицу, везан је, дакле, за друге људе или апстрактне појмове.

Прилог dokořán је описан на сљедећи начин:

- dokořán (*dokořen) přísl. (o něčem, co se rozevírá) úplně, docela (SSJČ), односно ииром, сасвим (ЧСР), али говорник чешког језика ће овај прилог употријебити искључиво у изразима otevřit/nechat/být/zůstat dokořán или údivem otevřel ústa dokoř́n у значењу зинуо је од чуда (ЧСР), сврстаним у фраземе.

Кад је ријеч о изразу ani nedutal, могло би се очекивати постојање глагола dutat, међутим, у рјечнику наилазимо само на одредницу nedutat с објашњењем у виду примјера спојева mlči ani nedutá, děti ani nedutaly (SSJČ). Први примјер је и једини опис значења датог глагола у Чешко-српском речнику са наведеним еквивалентом ћути, ни да писне (ЧСР). ${ }^{7}$

Наредни спој који смо издвојили nechat/zůstat na holičkách садржи предлошко-падежну конструкцију na holičkách. У рјечнику постоје хомонимне одреднице holička, прва као облик женског рода именице holič (берберин), а друга у трима, врло различитим значењима:

- holička 1. též holinka nedozrálé ovoce po odkvětu; 2. ob. ve spoj. zůstal se svými záměry na holičkách nedozrály, neuskutečnily se, zůstat, octnout se, být, sedět na holičkách být v koncích, nesnázich, ve velké tísni, nevědět si rady; nechat někoho (sedět) na holičkách opustit, zradit; 3. euf. holá, nahá hýždě, zadnice (SSJČ); односно 1. дијал. зелено, недозрело воће; 2. еуф. (гола) задюиияа, а после знака за увођење устаљених израза слиједе примјери zůstat, octnout se, být na holičkách у значењу остати на изедилу, у бубюу (ЧCP). Slovník spisovné češtiny (SSČ) наводи само значење жене holiče и хомоним који се објашњава фраземом octnout se, být na holičkách. Међутим, како Чермак наводи, овдје није ријеч о леми holička, јер нам ниједан други падеж није познат осим овог локатива множине, нити узус изузев датог фразема, те је ријеч само о облику (Čermák 2014).

${ }^{6} \mathrm{Y}$ рјечнику Slovnik spisovné češtiny (SSČ) под именицом úkor наведено је да спој na úkor има предлошку функцију и да иде уз 2. падеж.

${ }^{7}$ У рјечнику Slovník spisovné češtiny (SSČ) постоји формална одредница dutat која упућује на nedutat. Ова друга је пак без детаљнијег описа значења објашњена циркулус вициозус дефиницијом, што Чермак коментарише на сљедећи начин: „Slovník [Slovník spisovné češtiny] tu předstírá, jakoby slovo dutat existovalo (uvádí ho v hesláři), ale honem odkazuje k jeho skutečně užívané záporné podobě nedutat, kde se však místo aspoň nějaké definice nabízí nepřijatelně jen jeho synonymum (nemukat), a tedy skrytá a možná definice kruhem. Jediné, co se uživatel tedy dozví vedle této náhražky definice, je př́klad mlčel, ani nedutal. Nedozví se tedy, že nedutat a jeho časované podoby se užívají pouze v negaci, ani to, že obligatorní součástí tohoto frazému je částice ani'(Čermák 2014). 
Између ријечи затворене колокативне парадигме издвојили смо и два израза са придјевима: dát někomu něco na rozmyšlenou и v převážné většině. Rozmyšlená се као одредница налази од поменутих приручника једино у Чешкосрпском речнику са објашњењем у виду примјера na rozmyšlenou у коме је и у јединој употреби у чешком језику: dát, mít čas na rozmyšlenou са еквивалентом дати, имати времена за размишьљање и lhưta na rozmyšlenou у значењу рок за размишььағе (ЧСР). У номинативу једнине се не употребљава, као ни у једном другом падежу; мушки род не постоји и као одредница не налази ни у једном од двају поменутих чешких једнојезичних рјечника. Што се тиче другог придјева převážný, он као одредница постоји у свим наведеним приручницима, еквивланет у српском језику је претежан (ЧСР), али примјери у њима, као и ЧНК, показују да се користи у највећем броју случајева у женском роду и то у трима облицима převážnou, převážná и převážné, ${ }^{8}$ као и да је у чешћој употреби прилог рг̌evážně (са фреквентношћу 45,92 на милион ријечи у корпусу SYN2015).

Ову област ријечи врло затворене колокативне парадигме тј. област лексема ограничене колокабилности Чермак назива периферијом језика. Периферија језика би се могла објаснити као поље необичних околности под којима се ријечи удружују - комбинаторна периферија језика.

4.

Поред Чешко-српског речника еквиваленте представљених спојева са моноколокабилним ријечима смо потражили у и Чешком националном корпусу. У ту сврху смо користили паралелни корпус InterCorp, ${ }^{9}$ тачније InterCorp v12 Serbian из 2019. године, величине више од 30 милиона корпуних ријечи. У оквиру чешко-српског корпуса постоје двије колекције превода, а ми смо се усредсредили на ону састављену од превода књижевних дјела и ручно поравнану на нивоу реченица, која чини тзв. језгро корпуса, а у оквиру њега на дјела написана на српском односно чешком језику (ријеч је о преводима дјела И. Андрића, Д. Ћосића, 3. Ћирића односно К. Чапека, М. Кундере, Б. Храбала и др.). У језгро корпуса не улазе само дјела српских и чешких писаца већ и преводи са трећег језика и број појављивања дате ријечи се тиче свих превода, али смо за примјере узимали искључиво реченице српских и чешких аутора.

Апликација Treq Датабазе преводних еквивалената ЧНК-а као најфреквентнији еквивалент прилогу najevo показује предлошко-падежну конструкцију до знањ $::^{10}$

${ }^{8}$ У корпусу SYN2015 број појавница за придјев převážný у мушком роду је 10 (převážným 6, přváźný 3 и přvevážného 1), у средњем роду 1 (př́vážného). Придјев у женском роду се у истом корпусу јавља више од 700 пута.

\footnotetext{
${ }^{9}$ https://intercorp.korpus.cz

${ }^{10} \mathrm{https}$ ://treq.korpus.cz/index.php.
} 


\begin{tabular}{|c|c|c|c|}
\hline$\Delta$ Frekvence $\boldsymbol{\nabla}$ & $\Delta$ Procenta $\boldsymbol{\nabla}$ & $\boldsymbol{\Delta}$ Čeština $\boldsymbol{\nabla}$ & $\Delta$ Srbština \\
\hline 33 & 13.6 & najevo & do znanja \\
\hline 15 & 6.2 & najevo & pokaže \\
\hline 14 & 5.8 & najevo & se \\
\hline 12 & 4.9 & najevo & $\underline{\text { na znanje }}$ \\
\hline 11 & 4.5 & najevo & $\underline{\text { na videlo }}$ \\
\hline 8 & 3.3 & najevo & pokazala \\
\hline 8 & 3.3 & najevo & pokazao \\
\hline 7 & 2.9 & najevo & pokazuje \\
\hline
\end{tabular}

Међутим, даљом претрагом дошли смо до сљедећих резултата:

Еквиваленти за спој dát/dávat najevo су:

показати/показивати (191)

показати (89):

1) Zoufale se snažila nedat ničím najevo, že chápe jeho pravé úmysly [...]

Mnogo joj je bilo stalo da ničim ne pokaže da shvata njegove namere onakve kakve su [...] (ИАа)

показивати (102):

2) Major Gavrilo Stanković dává najevo jen hrdost, jež musí nějak souviset s tou jeho svatou spravedlností.

Major Gavrilo Stanković pokazuje samo ponos koji mora biti u nekom srodstvu sa onom njegovom svetom pravdom. (ДЋ)

Затим дати/давати/ставити/стављати до знања (44), од тога:

ставити/стављьати до знања (27)

ставити до знања (19)

3) Chovala se vesele, dokonce trochu hlučně, a snažila se mu dát najevo, že se u něho stavila jen náhodou. (MK)

Bila je vesela, čak ne i převise bučna, i nastojala je da mu stavi do znanja kako je svratila kod njega tek slučajno.

\section{стављати до знања (8)}

4) „Pořád nevím, proč jsi ke mně přišel,” hladil si špičatou bradu, čímž mi dával najevo, že ho moje váhání obtěžuje.

„Još uvek ne znam zašto si došao kod mene”, trljao je špicastu bradu, stavljajući mi do znanja da ga moje oklevanje zamara. (3h) 
дати/давати до знања (17)

дати до знаға (9)

5) To mu musíš dát jasně najevo! (MK)

To mu moraš jasno dati do znanja.

давати до знања (8)

6) Dávala mu najevo svou radost, svou vášeň, svůj souhlas, svou touhou žít navždy s ním. (MK)

Davala mu je do znanja svoju radost, svoju strast, svoju saglasnost, svoju želju da živi s njim do kraja života.

Поред предлога до постоји варијанта са предлогом на:

дати/давати на знање (19)

дати на знағе (7)

7) [...] a za hodinu jsem už viděl, že ten starý vrchní mne očima pohladil a dal mi tak najevo, že se mu líbím [...] (БX)

[...] i kroz jedan sat sam video kako me je taj stari glavni kelner pomilovao očima i tako mi dao na znanje da mu se dopadam [...]

давати на знање (12)

8) [...] kývali na mne, a pohybem ruky mi dávali najevo, že mne litují [...] (БX)

[...] klimali su mi, a pokretom ruke su mi davali na znanje da me sažaljevaju [...]

Еквиваленти изразу vyjít najevo, који се у корпусу јавља укупно 14 пута, су спојеви са лексемом видело: избити/изаћи/изићи на видело.

9) Všechno vyšlo najevo.

Sve je izbilo na videlo. (ИАа)

и једном се појављује vycházet najevo са еквивалентом излазити на видело:

10) Kus po kuse vycházela najevo celá pravda.

Malo-pomalo izlazila je na videlo cela istina. (ИАа)

Лексема видело је за нас занимљива својом колокативном парадигмом. Комбинаторни опсег је везан за глаголе изићи, избити, доћи, изнијети. Значење лексеме у Речнику српскохрватског књижевног и народног језика (РСАНУ) је сљедеће:

- видело, ијек. видјело $c$ 1а) светлост, светлосни зраци б) дневна светлост, дан в) покр. календарски дан, 2а) небеско тело које светли б) извор вештачке светлости 3) вид 4) видик. Слиједе устаљени изрази: изићи, излазити, изби(ja) 
ти, доћи на видело; изнети, износити на видело, ступити на видело у значењима „постајати јасан, обелодањивати, појавити се“.

Она се у савременом српском језику користи управо у овим устаљеним спојевима. Не постоје колокације *упалити/укључити видело, премда лексема може значити и „извор вештачке светлости”, већ је превасходно у употреби у значењима 1a) ${ }^{11}$ и 1б) са ограниченом колокабилношћу, како закључујемо на основу претраге у Корпусу савременог српског језика. ${ }^{12}$ У SrpKor 2013 величине 122 милиона корпусних ријечи се лексема видело појављује у спојевима:

- на видело (667 појављивања) изаћи/истерати на видело, изнети/износити на видело и избити/избијати на видело;

-за видела (12 појављивања);

- дневно видело (1) у дјелу Том Сојер Марка Твена.

Ово нас наводи на закључак да видело јесте лексема у српском језику врло ограничене колокабилности.

Сљедећа моноколокабилна ријеч у чешком језику је úkor. У паралелном корпусу InterCorp као еквиваленте за израз na úkor проналазимо:

на рачун (11):

11) Apeluji na carskou vládu, aby nejednala s Itálií na úkor území nasáklých slovanskou krví.

Apelujem na carsku vladu da ne pregovara sa Italijom na račun Dalmacije i Hrvatske, koje su odlučne da se ujedine sa Srbijom. (ДЋ)

на umemy (1):

12) Velcí se i za této války dohodnou jedině na úkor malých.

Veliki će se i u ovome ratu sporazumeti jedino na štetu malih. (ДЋ)

И за израз jít na úkor еквивалент је сносити (1): (АЛ)

13) [...] mimo velké výdaje, o nichž byla řeč prve a které nejdou na jejich úkor.

[...] izuzevši velike izdatke koje sam malopre pomenuo, a koje oni neće ni snositi.

Нашој наредној лексеми ограничене колокабилности, прилогу dokořán, најчешћи еквивалент је широм; оба прилога се јављају са трпним глаголским придјевом глагола otevřit, односно отворити (192) у придјевској служби:

14) Když vstoupil dokořán otevřenými dveřmi do ložnice, zarazil se nad nevídaným nepořádkem [...]

${ }^{11}$ У Новом завјету у преводу В. С. Караџића стоји: „Исус им, пак, рече: Ја сам видјело свијету: ко иде за мном неће ходити по тами, него ће имати видјело живота" (Јн 8:12). У новом, синодалном преводу употребљена је свјетлост (Свето писмо 2014).

${ }^{12} \mathrm{http}: / /$ www.korpus.matf.bg.ac.rs 
Ulazeći u spavaonicu kroz širom otvorena vrata, zastade pred neviđenim neredom [...] (ДЋ)

За израз mít něco dokořán јављају се три еквивалента: зијати (1), бити разјапљен (6), односно разгорачен (5):

15) Dobře, dobře, at’ si je hodný a poctivý, ale jestli ho ještě jednou nachytám, že má krám dokořán a bez dozoru, neprojde mu to jen tak lehce.

Lepo, lepo, neka je dobar i pošten, ali ako još jednom nađem da mu dućan zija bez nadzora, neće ovako lako proći. (ИАб)

16) [...] nedal si chvíli pokoj a velká ústa měl neustále dokořán.

[...] nije se smirivao, i velika usta neprestano su mu bila razjapljena (МБ)

17) Paní Dafina ležela upravená a klidná s velikýma, dokořán otevřenýma očima, s rukama podél těla [...].

Gospođa Dafina ležala je čista i mirna, velikih, razgoračenih očiju, ispruženih $\operatorname{ruku}[\ldots] .(\mathrm{MЦ)}$

Еквиваленти за израз ani nedutal су разноврсни и сви се јављају са учесталошћу од једног појављивања: мудро сам ћутао, завладао је тајаu, није изустио ни речи; међутим, ниједан не налазимо у дјелима превода српских или чешких књижевника.

Израз holičkách се у паралелном корпусу појављује у спојевима nechat/ nechávat na holičkách (8) са еквивалентима оставити/остављати на ичедилу (6), подвалити (1), дизати руке од некога (1) и zůstávat na holičkách (1) са еквивалентом не вредети. Нашли смо само примјер у преводу романа са српског језика, у преведеним дјелима са чешког их засад нема.

18) Už i Rusové nás nechávají na holičkách? - zeptal se Aleksandar.

Zar i Rusi dižu ruke od nas? - upita Aleksandar. (ДЋ)

Придјев rozmyšlenou у споју čas na rozmyšlenou, коме претходе глаголи vyžádat si/ponechat/získat/mít/dát, јавља ce у 11 појавница од укупно 21. У осталим случајевима су то именице chvile, týden, den умјесто čas. Најчешћи еквиваленти су оставити/имати/дати времена за размишљљање (9) и оставити/имати/дати времена да размисли (6); у осталим случајевима су: да размислим (4), да промисли (1) и да мисли (1). Све еквиваленте смо пронашли код превода са трећег језика изузев:

19) Dostal dva týdny na rozmyšlenou, načež ho znovu povolali před vyšetřovatele a nabídli mu chlebíčky a cigaretu.

Posle petnaest dana, vreme koje je ostavljeno Novskom da razmisli, bio je ponovo pozvan pred istražitelja i bio ponuđen sendvičima i cigaretom. (ДК)

Кад су у питању придјев převážná и прилог převážně, у паралелном корпу- 
су се придјев јавља најчешће у облику споја převážná část (4) у преводима са трећег језика и еквивалентом већи део (за разлику рјешења претежна већина које нуди ЧСР), док су прилози углавном (26) и претежно (7) еквиваленти прилогу рг̌evážně.

5.

Анализа датих спојева показала је особен комбинаторни потенцијал обрађених лексема у виду њихове спојивости са мањим бројем других лексема. Све моноколокабилне ријечи које смо анализирали помоћу лексикографских приручника и електронских корпуса и њихови еквиваленти појављују се у савременом чешком и српском језику. Семантика и најчешћи колокати, у већој или мањој мјери већ обрађени у поменутим рјечницима (Slovník spisovného jazyka českého, Slovník spisovné češtiny и Чешко-српски речник) бивају јаснији и допуњени на основу узуса из Чешког националног корпуса. Еквиваленти које смо у српском језику пронашли у паралелном корпусу су, такође, показали фреквентност пандана наведених у приручнику, али открили су нам и нека нова рјешења. Ово се посебно односи на изразе: na holičkách, dokořán, na úkor и přvéźň́á část.

Колокација у којој једног од колоката карактерише ограничен колокабилни опсег у чешком језику има немали број, а периферија језика као област таквих спојева представља богато поље истраживања примјенљиво у компаративном и конфротативном погледу јер се као еквиваленти у другом језику могу појавити лексеме такође специфичне колокабилности. У нашем случају је то лексема видело чије се колоцирање временом у савременом српском језику сузило на мањи број комбинација.

На основу анализе можемо закључити да корпусна истраживања осим што дају увид у узус одређеног језика, могу значајно помоћи у сагледавању еквивалентности и бити допуна штампаним приручницима. Управо путем испитивања на обимним корпусима могу се семантички прецизирати лексеме и њихов колокативни опсег.

\section{Цитирана литература}

Драгићевић, Рајна. Лексикологија српског језика. Београд: Завод за уџбенике, 2007. [Dragićević, Rajna. Leksikologija srpskog jezika. Beograd: Zavod za udžbenike, 2007]

Дражић, Јасмина. Лексичке и граматичке колокације у српском језику. Нови Сад: Филозофски факултет, 2014.

[Dražić, Jasmina. Leksičke i gramatičke kolokacije u srpskom jeziku. Novi Sad: Filozofski fakultet, 2014]

Стојичић, Виолета. „Стилске колокације у књижевном превођењу са српског језика на енглески“, Филолошки преглед 38/2, 2011, 195-203.

[Stojičić, Violeta. „Stilske kolokacije u književnom prevođenju sa srpskog jezika na engleski““. Filološki pregled 38/2, 2011, 195-203]

Čermák, František. Idiomatika a frazeologie češtiny. Praha: Karlova univerzita, 1982.

Čermák, František. „Kolokace v lingvistice“. [In:] F. Čermák, M. Šulc (eds.) Kolokace. Praha: Ústav českého národního korpusu, 2006, 9-16. 
Čermák, František. Frazeologie a idiomatika česká a obecná. Czech and general phraseology. Praha: Karolinum, 2007.

Firth, John Rupert. Papers in Linguistics: 1934-1951. London: Oxford University Press, 1957.

Heid, Ulrich. „On Way Words Work Together - Topisc in Lexical Combinatorics”. [In:] W. Martin (ed.) Proceedings of the VIth Euralex International Congress. Amsterdam, 1994, 226-257.

Palmer, Frank Robert. Semantics. A new outline. Cambridge: Cambridge University Press, 1976.

Prćić, Tvrtko. Semantika i pragmatika reči - drugo, dopunjeno izdanje. Novi Sad: Zmaj, 2008.

Riđanović, Midhat. Jezik i njegova struktura. Sarajevo: Izdanje autora, 1988.

Stojičić, Violeta. Teorija kolokacija. Beograd: Zadužbina Andrejević, 2010;

Stojičić, Violeta. „Sintagma i strukturna svojstva kolokacija“. Filolog: časopis za jezik, književnost i kulturu 5, 2012, 260-268.

\section{Извори}

ИАа: Андрић, Иво. Омерпаша Латас. Београд: Просвета, 1976.

[Andrić, Ivo. Omerpaša Latas. Praha: Melantrich, 1981. Překlad: Jiří Fielder]

ИАб: Андрић, Иво. На Дрини ћуприја. Београд, Загреб, Сарајево, Љубљана: Просвета, Младост, Свјетлост, Државна заложба Словеније, 1967.

[Andrić, Ivo. Most na Drině. Praha: Odeon, 1987. Překlad: Milada Nedvědová]

МБ: Bulatović, Miodrag. Crveni petao leti ka nebu. Zagreb: Naprijed, 1959.

[Bulatović, Miodrag. Červený kohout letí k nebi. Praha: Odeon, 1972. Překlad: Dušan Karpatský]

МЦ: Црњански, Милош. Сеобе. Београд: Просвета, 1966.

[Crnjanski, Miloš. Běženci panonských bažin. Praha: Odeon, 1981. Překlad: Milada Nedvědová]

Čermák, František. Periferie jazyka. Slovník monokolokabilních slov. Praha: Nakladatelství Lidové noviny, 2014.

ЧНК: Český národní korpus. https://korpus.cz>30. 6. 2021.

ЧСР: Качаник, Емилија et al. Чешко-српски речник I, II. Београд: САНУ, 2001.

[Kačanik, Emilija et al. Češko-srpski rečnik I, II. Beograd: SANU, 2001]

ДЋ: Ћосић, Добрица. Време смрти. Београд: Просвета, 1976.

[Ćosić, Dobrica. Čas smrti. Praha: Odeon, 1976. Překlad: Milada Nedvědová]

БX: Hrabal, Bohumil. Obsluhoval jsem anglického krále. Praha: Pražská imaginace, 1993.

[Hrabal, Bohumil. Služio sam engleskog kralja. Beograd: Agencija Trivić, 2005. Prevod: Dragoljub Matić]

ДК: Kiš, Danilo. Grobnica za Borisa Davidoviča. Beograd: BIGZ, 1976.

[Kiš, Danilo. Hrobka pro Borise Davidoviče. Praha: Mladá fronta, 1995. Překlad: Dušan Karpatský]

Korpus savremenog srpskog jezika. http://korpus.matf.bg.ac.rs>30. 6. 2021.

MK: Kundera, Milan. Nesnesitelná lehkost bytí. Toronto: Sixty-Eight Publishers, 1985.

[Kundera, Milan. Nepodnošljiva lakoća postojanja. Beograd: Gramatik, 2005. Prevod: Nikola Kršićc] 
АЛ: Lustig, Arnošt. Modlitba pro Kateřinou Horovitzovou. Praha, 1990.

[Lustig, Arnošt. Molitva za Katarinu Horovic. Beograd: Stubovi kulture. Prevod: Ana Adamović]

Oxford English-Serbian Student's Dictionary. Oxford University Press, 2006.

РСАНУ: Речник српскохрватског књижевног и народног језика. Београд, Српска академија наука и уметности, 1959-2010.

[Rečnik srpskohrvatskog književnog i narodnog jezika. Beograd, Srpska akademija nauka i umetnosti, 1959-2010]

SSJČ: Havránek, Bohuslav, Jaromír Bělič, Miloš Helcl, Alois Jedlička (eds.) Slovník spisovného jazyka českého I-IV. Praha: Československá akademie věd, 1960-1971.<Internetová jazyková př́ručka (cas.cz)>30. 06. 2021.

SSČ: Filipec, Josef Daneš, František, Machač, Jaroslav, Mejstř́ik Vladimír (eds.) Slovník spisovné češtiny pro školu a veřejnost. Praha: Ústav pro jazyk český Akademie věd ČR, 2007. $<$ Internetová jazyková př́ručka (cas.cz)>30. 06. 2021.

Свето писмо Старога и Новога завјета [превео Свето писмо Старога завјета Ђура Даничић, Свето писмо Новога завјета Вук Стефановић Караџић]. Београд: Партенон: Библијско друштво Србије и Црне Горе, 2004.

[Sveto pismo Staroga i Novoga zavjeta (preveo Sveto pismo Staroga zavjeta Đura Daničić, Sveto pismo Novoga zavjeta Vuk Stefanović Karadžić). Beograd: Partenon: Biblijsko društvo Srbije i Crne Gore, 2004]

Свето писмо: Нови завјет Господа нашега Исуса Христа. Свети архијерејски синод Српске православне цркве. Београд, 2014.

[Sveto pismo: Novi zavjet Gospoda našega Isusa Hrista. Sveti arhijerejski sinod Srpske pravoslavne crkve. Beograd, 2014]

3h: Ćirić, Zoran. Hobo. Beograd: Alfa, 2002.

[Ćirić, Zoran. Hobo. Praha: Runa, 2012. Překlad: Jan Doležal]

\section{Snežana Popović}

\section{THE CONCEPT OF MONOCOLLOCABILITY AND LANGUAGE PERIPHERY}

\section{Summary}

This paper discusses the ability of lexemes to connect with others and to build collocations. There are lexemes in the Czech language that collocate with an extremely small number of other lexemes called monocollocable words. We searched for some of them in the Czech National Corpus and in the InterCorp parallel corpus for their equivalents in Serbian. We also looked up their meanings in monolingual and bilingual dictionaries and in the Corpus of Contemporary Serbian.

There are many collocations in the Czech language where one of the components is characterized by a limited collocability, and the language periphery as an area of such word combinations represents a rich field of research applicable in the comparative and contrastive ways. The analysis of the monocollocable words showed a special combinatorial potential in the form of their co-occurrence with a smaller number of other lexemes. Corpus research can significantly help in understanding equivalence and be a complement to printed manuals.

Keywords: collocability, Czech language, Serbian language, Czech National Corpus, Corpus of Contemporary Serbian. 